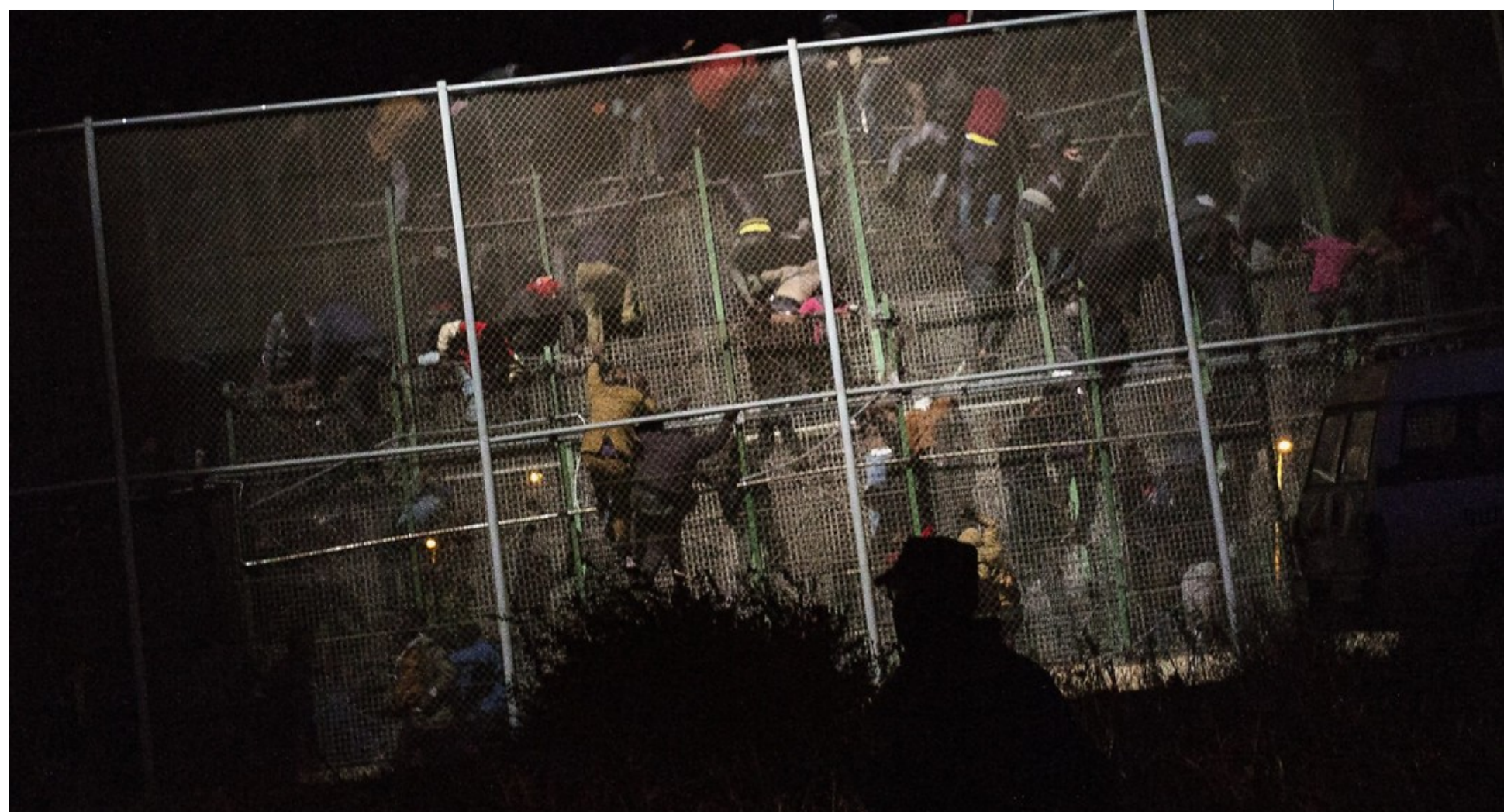

\title{
DO WE REALLY WANT TO FIX IMMIGRATION?
}

Published on October 19,2016 Edit article |

Ulysses Jaen
Director of the Law Library and
Assistant Professor of Law
10 articles

By Ulysses N. Jaen

If we do, we cannot continue to ignore the root causes of migration in our world. No matter how many physical barriers are constructed, if the reasons why people flee their lands are not ameliorated, they will find a way to defeat all barriers.

2 
of four categories: economic (6 million), student (4 million) million), and refugee/asylum ( 3 million). There are about 20 officially recognized refugees worldwide, with $86 \%$ of them neighboring countries, up from $70 \% 10$ years ago

Some key factors that need to be addressed include:

- People will do whatever it takes to survive and just like will keep coming regardless of military and physical barriers.

- Fear sells and having people fear each other is a good way to get their attention and support. The result is the rise of populist demagogues.

- The money spent on border security could be much better spent on alleviating the reasons why people are migrating. However, special interests such as for-profit prisons and defense industries want you to think their way works better.

- The war on drugs has not worked and creates and environment of lawlessness and corruption.

- Poverty and economic migration are a major result of international trade policies.

- Political instability and wars are exploited and exacerbated by special interests.

- Not addressing these issues comprehensively will result in more suffering, deaths, corruption, poverty and violence in a never-ending vicious cycle.

This new age of barriers is not just about razor wire, reinforced concrete walls, chain links and guards, planes, helicopters, drones, dogs and guns. It also reflects the effects of war, poverty and lack of economic opportunities and has led to the rise of populist politicians. The 
demonstrates deeply ingrained rejection of cultural, religiou assimilation, or integration.

These reactions suggest that globalization has marched forw mobility and investment, but has failed miserably to take int subversive resentment developing among those who feel thr who are not thriving, and those who are directly impacted $b$ : aftermath of international trade's only focus on profit for the ignoring the people who are left behind.

DHS Secretary Johnson, who is charged with finding solutions to these issues explains it clearly in his latest report, "Border security alone cannot overcome the powerful push factors of poverty and violence that exist in Central America. Walls alone cannot prevent illegal migration. Ultimately, the solution is long-term investment in Central America to address the underlying push factors in the region. We continue to work closely with our federal partners and the governments in the region, and are pleased with the $\$ 750$ million Congress approved in FY 2016 for support and aid to Central America. We urge Congress to provide additional resources in FY 2017.’[1]

How do we find solutions? Take international trade for instance, Trade agreements such as the North American Free Trade Agreement (NAFTA) and the Central American Free Trade Agreement (CAFTA) excluded most issues related to labor mobility. NAFTA has generated significant benefits for US, Canadian and Mexican businesses at the same time that it reduced the value of the Mexican currency by over $20 \%$ and increased the cost of basic staples such as tortillas by more than 500\%.[2] A 2014 PIIE study of NAFTA's effects found that about 15,000 jobs on net are lost each year due to the pact - but that for each of those jobs lost, the U.S. economy gains roughly $\$ 450,000$ in the form of higher productivity and lower consumer prices. The benefits mean very little to the displaced workers who need alternatives for improvement to be included in those gains. 
rarely thought about how its policies to encourage economic in poorer countries might affect immigration; similarly, it ha thought about how its immigration policies might affect dev This contrasts with Europe, where full membership in the El Union-which includes the right for citizens of one EU coul in any other-has been conditional on reaching certain econ benchmarks.'[3]The European model was never designed tc mass influx of refugees from the Middle East and northern rise to the Brexit movement and anti-immigrant sentiment.

There are over 250 million international migrants around the globe, of whom 21.3 million plus are classified as refugees. South-South migration is larger than in South-North migration. Intra-regional migration is large in Europe and Central Asia, the Middle East and North Africa, and SubSaharan Africa. Many of the World Bank's client countries-for example, India and South Africa - are large destination countries for migrants. Income gaps and inequality, demographic imbalances, and environmental changes suggest that migration pressures will continue for the foreseeable future. In 2015, the ratio between the average income of the high-income countries and that of the low-income countries stood at 70:1. It will take decades before these gaps are closed.[4]

As a small businessman, I have tried my best to compete with producing and marketing agricultural products, finished goods and value-added services in Latin America, only to find that the corporate farming competitors and current socio-economic realities are simply overwhelming. Access to the markets, financing, distribution is not viable for small entrepreneurs. Proponents routinely point out how countries with greater financial inclusion are wealthier and less unequal. The World Bank's 2014 Global Financial Development Report, for instance, heavily discusses these correlations. However, it costs me more to plant the seeds that it costs for the finished product to be on the shelves of the ubiquitous Walmart and affiliates. When I tried to diversify into aquaculture, the cost of raising fish was much higher than what China can put the fish on the table, and already cooked. As I turned for help from officials and 
they give major economic incentives and tools to the larger ] expense of my small business' stability.

The book Portfolios of the Poor, explains that financial serv managing volatile and irregular incomes. However, loans at rates are not a solution if the funds don't enable me to comp having enough money is bad enough. Not being able to man money you have is worse. This is the hidden bind of poverty small, productive farm is nearly extinct and the farmers and their workers must find somewhere else to live or resign themselves to substandard living conditions where they are. To get financing, the farm is put up for collateral, the crops yield but the market is flooded with competing product, the loan demand high interest servicing and goes unpaid and the farm is ultimately lost .

Governments and international organizations such as the World Bank and the International Monetary Fund can reduce the economic reasons for immigration and enhance the positive results of global trade. We know that remittance by migrants to their countries of origin reduce poverty and the need for others to join them. Some politicians wrongly suggest that increasing the cost of monetary transactions will reduce incentives for migration and provide funds for building more barriers. This line of reasoning is flawed as it will only create another source for criminal enterprise to rise that would fill the need for monetary transactions to occur. One much better way of providing additional funds would be to reduce remittance and recruitment costs and mobilize philanthropic contributions from the diaspora (World Bank 2015). Diaspora savings (estimated to be $\$ 500$ billion) could be mobilized via issuance of diaspora bonds. Such financing would have greater impact if it were used to finance programs the diaspora favors (infrastructure, schools, hospitals).

World Bank Group involvement in such projects could help reduce the lack of trust that many Diasporas have in the governments back home. The International Finance Corporation (IFC) could help scale up the impact of migration on development by facilitating the engagement of the 
supporting micro-, small, and medium-size enterprise lendir for immigrants in the host country); providing vocational an skills and supporting entrepreneurship (through venture capj start-ups, incubators, and accelerators in both host and home and leveraging its convening power to explore public-privat that provide services to and fund projects that benefit migral

Financing tools are crucial for economic development, the $r$ poverty and migration. When asked to explain why microfinance institutions were shifting towards local sources of funding, experts cited "increased availability" and "better pricing" as the two main reasons. [6] These trends need to be reversed in order to scale microfinancing globally. In an innovative pilot, the IFC provided a loan backed by future remittances to Fedecredito in El Salvador. Since the mid-1990s, commercial banks in Brazil, Mexico, and Turkey have raised billions of dollars by issuing international bonds backed by future remittances and payment rights. A proper accounting of remittances could also enhance sovereign credit ratings and reduce borrowing costs.[7]

\section{WEAPONS AND VIOLENCE INCREASE IMMIGRATION:}

Other major problems such as the exportation of weapons into Mexico and Latin America from the U.S. that has been reported at over 2000 illegal weapons a day play a major role.[8] According to data from the Department of Justice's Bureau of Alcohol, Tobacco, Firearms and Explosives (ATF), 73,684 firearms (about 70 percent) seized in Mexico and traced from 2009 to 2014 originated in the United States.[9] The proliferation of weapons has turned Latin America into gruesome crime scenes as the drug cartels overrun society in their efforts to satisfy the World's demand for cheap drugs leaving a trail of violence, corruption, desolation, and chaos. "In Mexico the war on drugs turned out to be a worse evil than the one it set out to fight." [10] Guatemala, Honduras and El Salvador suffer from the highest homicide rates in the world. "What is causing the violence? The nature of the violence is distinct in each country, but there are common threads: the proliferation of gangs. the 
rates of impunity are major factors contributing to insecurity region.’[11]

Heroin production has also increased to record levels. [12] C production has also risen and has been driven by the same $\mathrm{c}$ Colombia despite billions of dollars in military aid to eradic that country. "Since the beginning of Plan Colombia, the US has given Colombia over $\$ 5$ billion with the vast majority going to Colombia's military and police."[13] According to the White House Office of National Drug Control Policy, coca cultivation increased by 39.1 percent in 2014 , then a further 42.5 percent in 2015. Nationwide, coca cultivations increased by 42.5 percent -- or 47,532 hectares -- in 2015, reaching a total of 159,377. Compared to previous White House figures, this outstrips the 39.1 percent increase seen between 2013 and 2014. According to the White House data, the total cocaine production potential of Colombia in 2015 was 420 metric tons, up from 250 the previous year.[14]

The statistics demonstrate that the production and consumption of drugs keeps growing. However, the countries affected by the drug trade are unable to control it and their people are being forced to migrate. The biggest winners in the climate of violence and political instability include the global aerospace and defense industries. According to a new report by the accounting firm Deloitte, "the resurgence of global security threats" promises a lucrative "rebound" in defense spending.[15]

The Deloitte report alerts investors that "revenue growth" is "expected to take a positive turn" due to the terrorism and war in the Middle East and the tensions in Eastern Europe and the South China Sea. 
serious ramitications that strengthen criminal and corporate the same is true in other parts of the world. In Europe, speci are also benefiting from the border wars.

The report, Border Wars: The Arms Dealers Profiting from Europe's Refugee Tragedy, released jointly by the European Stop Wapenhandel and Transnational Institute (TNI), outlines arms traders' pursuit of profit in the 21 st century's endless conflicts. "The human rights of refugees play no real role in this thinking, except for promotional purposes." according to Mark Akkerman, Stop Wapenhandel.

"There is one group of interests that have only benefited from the refugee crisis, and in particular from the European Union's investment in 'securing' its borders,"' the report finds. "They are the military and security companies that provide the equipment to border guards, the surveillance technology to monitor frontiers, and the IT infrastructure to track population movements." Indeed, "from 2005 to 2014, EU member states granted arms exports license to the Middle East and North Africa worth over 82 billion euros," according to the report.

The so called, Americans for Peace, Prosperity, and Security organization is a new group whose main mission is to encourage continued global militarism.[16] The APPS was formed by current and former officials from Raytheon, BAE Systems, SAIC, and other major defense contractors. Lobbyists who represent the defense industry are also involved. Rogers, the former House Intelligence Committee chairman who retired from Congress last year, also represents private clients, though he has refused to disclose them.

Their mission is clear to anyone who cares to be informed. To "help elect a president who supports American engagement and a strong foreign 
encourages presidential candidates to take hawkish position: are favorable for the lobbyists' clients, and most major cand are embracing extremely hawkish policies to confront politi recent statistics are anything to go by, future developments $\mathrm{i}$ the worldwide trend of military expenditure are not expecter hopeful reading for those who advocate global disarmament

In the absence of newly declared war, how would the military-industrial complex prosper without terrorism? (Image: KAZ Vorpal) The National Priorities Project recently sent out an email with the subject line, "Terrorism means business, if you're a defense contractor." The message bluntly states:

If you're a defense contractor, terrorism means business, and business is good. According to recent reports, the corporate defense behemoth Lockheed Martin's revenue rose $15.7 \%$ and shares rose $1.5 \%$ following the news that President Obama was committing an additional 250 troops in Syria.

Lockheed Martin was the biggest federal contract in 2014, pulling in more than $\$ 32$ billion in federal contracts, including \$25 billion in Pentagon contracts. Its federal haul makes it practically an honorary state.

In fact, the Project states that the contracts received by Lockheed Martin in 2014 exceed federal grants allotted to each individual state, with the exceptions of the high-population states of California, New York and Texas.

\section{DO BORDER WALLS REALLY WORK?}


reality is that various Chinese kingdoms built multiple walls which have been lost to history-over a 1,500-year period t Mongol raids. The evidence of the oldest walls, said to have 220 BCE, is thin: a single vague mention of fortifications in text written more than 100 years after the fact. If a wall was years ago, no evidence of it remains today. In the ensuing ce walls were built out of tamped earth, but these were often se and left to erode.’'[18]

This phenomenon was demonstrated in the 1990s on the U.S.-Mexico border when the first sections of fencing were built in El Paso and near San Diego, supported by large deployments of Border Patrol agents. In the weeks that followed, crossings in those sectors dropped to almost zero. Similarly, the construction of Hungary's border fence in 2015 was backed up with border guards, and consequently, crossings dropped substantially. However, in both cases fortified walls did not prevent crossings into the United States and European Union entirely, but instead shifted flows to other locations that were more remote or less fortified.

In the U.S. case, as high-traffic urban routes were closed, migrants and smugglers began to cross in the remote and dangerous deserts of western Arizona. Tunnels are built, new devices and methods are invented. Child migration from Central America to the United States, which surged in 2014, has also been undeterred by enforcement (in fact most unaccompanied minors turn themselves in to border agents), as tens of thousands of children from El Salvador, Honduras, and Guatemala spontaneously arrive at the U.S. border with Mexico to claim asylum. Efforts to dissuade would be migrants are not working. The Central American Minors (CAM) Refugee/Parole Program provides certain qualified children in E1 Salvador, Guatemala and Honduras a safe, legal, and orderly alternative to the dangerous journey that some children are currently undertaking to the United States.[19] The reduction in entries of unaccompanied children is likely the result of Mexican repression against immigrants in their southern border. But advocates charge that the policy has not worked. The number of unaccompanied children who crossed the 
2015 but has swelled again to 54,000 this year, according to statistics. "The reasons for that are quite simple: The root ca migration have continued unabated - violence in the regior trafficking," Wendy Young, president of Kids in Need of De Tuesday during a conference in New York sponsored by the Migration Studies.[20]

In the European migration crisis in 2016, once land routes th Balkans were closed, migrants adjusted by shifting their routes to board boats across the Mediterranean, frequently from Libya. The results are tragic death tolls climbing before our very eyes. At the U.S.-Mexico border this was evident in the decline in deaths in California which coincided with a rapid rise in Arizona. The Tucson, Arizona coroner's office saw a substantial increase in the number of migrant deaths in the years after the hardening of the border, as migration routes shifted to the more dangerous deserts. "The Tucson morgue recorded an average of 18 migration-related deaths per year in the 1990's, while in the 2000's it saw almost 200 per year. In 2010 the Border Patrol found more than 250 bodies in the Tucson sector, despite a decline in the total number of border apprehensions. Similarly, when the European Union and Member States fortified borders in 2015, there were a record 3,771 reported deaths at the edges of the European Union. In 2016, with the easier land route through the Balkans and Eastern Europe closed, the rate of deaths has increased further, with more than 3,000 deaths recorded through July - a 50 percent increase from the previous year. By comparison, there were just a handful of deaths recorded annually at the edges of Europe in the 1990's, and never more than 800 deaths prior to 2006." [21]

\section{NOT ADDRESSING THE REASONS FOR IMMIGRATION IS COUNTERPRODUCTIVE.}

When we recognize that barrier walls are not the solution, we can take steps to alleviate the push/pull root causes of immigration. The first step is to address the pull factors by providing work permits to the workers needed by the US and European economies. Changing our priorities to 
migrants that our country's economy needs will change the : Instead of suggesting that our children take over those jobs 1 want to do ourselves, let's educate our children to compete $\mathrm{i}$ economy with the right education and skills.

Attack the major push factors: poverty and violence. Let's ir developing our continent's economies with fair trade agreen to financing and training, and favorable policies that suppor leaderships.

Let's take a closer look at the war on drugs by legalizing some use while taxing and controlling them like we do alcohol, tobacco and pharmaceuticals. Stop wasting money and resources to imprison nonviolent people caught up in this underworld. Let's stop the arms and drugs smuggling trades and drain their cartels' bank accounts.

Let's reduce income inequalities that force rural communities to migrate to cities and from undeveloped nations to developed economies by investing in the people, not their governments. Lending or giving money to a government so that they can help their cronies or buy more weapons is counterproductive. Let's help the would-be migrants before they decide to leave home. Let's also help those we want to come, to do it legally, and according to our country's needs. It is long overdue, what we need is humane, comprehensive, immigration reform.

Sources include:

[1] Statement by Secretary Johnson on Southwest Border Security Release Date: October 17, 2016 available at: https:/www.dhs.gov/news/2016/10/17/statement-secretary-johnsonsouthwest-border-security

[2] Economists largely agree that NAFTA has provided benefits to the North American economies. Regional trade increased sharply (PDF) over the treaty's first two decades, from roughly $\$ 290$ billion in 1993 to more 
U.S. foreign direct investment (FDI) stock in Mexico increa period from $\$ 15$ billion to more than $\$ 100$ billion.

[3] Council on Foreign Relations. Independent Task Force o Immigration Policy, Jeb Bush, Thomas F. McLarty - 2009

[4] MIGRATION AND DEVELOPMENT A Role for the U Group September 2016 http://pubdocs.worldbank.org/en/468881473870347506/Migration-andDevelopment-Report-Sept2016.pdf

[5] Portfolios of the Poor: How the World's Poor Live on \$2 a Day By Daryl Collins, Princeton University Press, Dec 19, 2010.

[6] MICROFINANCE MARKET OUTLOOK “The responsibility Microfinance Market Outlook 2016 aims to provide an in-depth and concise overview of the expected developments in the industry over the next year." Developments, forecasts, trends 2016. http://www.responsability.com/funding/data/docs/en/17813/MicrofinanceOutlook-2016-EN.pdf

[7] Supra footnote 3 at 39-40.

[8] http://www.insightcrime.org/news-analysis/seizures-raids-thrivinglatam-arms-trafficking-trade

[9] http://www.gao.gov/products/GAO-16-223

[10] http://www.nytimes.com/2016/10/10/opinion/a-decade-of-failure-inthe-war-on-drugs.html?_r=0

[11] Central America's Violent Northern Triangle Author: Danielle Renwick Updated: January 19, 2016 http://www.cfr.org/transnationalcrime/central-americas-violent-northern-triangle/p37286 
soars/article/2002449

[13] U.S. Policy in Colombia, Amnesty International, http:/www.amnestyusa.org/our-work/countries/americas/co policy-in-colombia

[14] http://www.insightcrime.org/news-analysis/coca-boomcolombia-could-spell-trouble-for-peace-plans

http://www2.deloitte.com/content/dam/Deloitte/global/Documents/Manuf acturing/gx-manufacturing-2016-global-ad-sector-outlook.pdf

[16] https://theintercept.com/2015/12/11/defense-contractors-laudthemselves-for-steering-candidates-toward-militarism/

[17] https://www.statista.com/topics/1696/defense-and-arms/

[18] Borders and Walls: Do Barriers Deter Unauthorized Migration?

Jones, Reece 10/05/2016 http://www.migrationpolicy.org/article/bordersand-walls-do-barriers-deter-unauthorized-migration

[19] https://www.uscis.gov/CAM

[20] https://supportkind.org/media/obama-thanks-mexico-absorbingcentral-american-refugees-administration-wants-turn-away/

[21] Supra note 18. 
$\mathrm{O}$
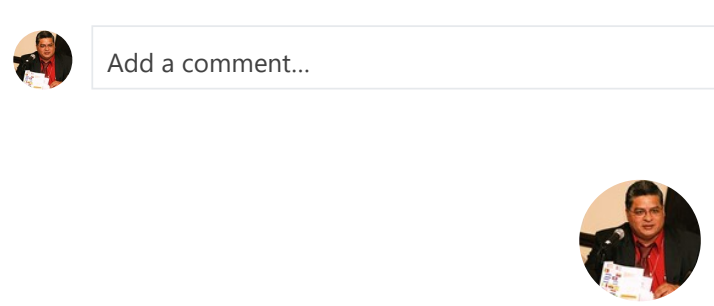

Ulysses Jaen

Director of the Law Library and Assistant Professor of Law

More from Ulysses Jaen See all 10 articles

"E PLURIBUS UNUM Out of many, one." That's what...

Ulysses Jaen on Linkedln

\section{Judicial Misinterpretation}

Ulysses Jaen on Linkedln
The Immigration Dilemma

Ulysses Jaen on Linkedln
Medical M glance:

Ulysses Jaen 